\title{
VULVAR SYRINGOMA: A RARE CASE REPORT
}

\author{
Cihangir Mutlu ERCAN, Hakan COKSUER, Kazım Emre KARASAHIN, Ibrahim ALANBAY, Iskender BASER
}

Department of obstetrics an Gynecology, Gulhane Military Medical Academy, Ankara, Turkey

\begin{abstract}
SUMMARY
Syringomas are intraepidermal eccrin sweat gland adenomas which can usually be seen in adolescent ages. Typical involvement includes the malar areas and the lower eyelids, however vulvar involvement is rare. These lesions are characterized with papules which are small, yellowish, firm seperated from each other and can be 1-5 mm in diameter, and are often associated with increased vulvar discomfort and itching. The lesions are generally multiple, bilateral and symmetrical. A 35-year-old woman presenting with a 3-year history of vulvar papules, sometimes itching and increasing in time is presented to our clinic. The patient has been diagnosed as syringoma with clinical and histopathological results. Due to the fact that the patient is symptomatic, we preferred laser vaporization as a treatment option and presented our case with the preoperative and postoperative pictures.
\end{abstract}

Key words: laser vaporization, vulvar syringoma

Journal of Turkish Society of Obstetrics and Gynecology, (J Turk Soc Obstet Gynecol), 2012; Vol: 9 Issue: 2 Pages: 116- 9

\section{VULVAR SÍRINGOMA: NADİR BİR OLGU SUNUMU}

\section{ÖZET}

Siringomalar, sıklıkla adölesan dönemdeki kadınlarda görülen intraepidermal ekrin ter bezi adenomalarıdır. Tipik tutulum malar bölgeler ve alt göz kapaklarında iken, vulvar tutulum oldukça nadirdir. Lezyonlar, küçük, sarımsı, birbirinden ayrl, 1-3 mm boyutlarında papüllerle karakterize olup sılklkla vulvar rahatsızlık ve kaşıntı ile birliktelik gösterirler. Lezyon karakteristiği; genellikle multipl, bilateral ve simetrik oluşudur. 35 yaşındaki olgumuz, vulvada yaklaşık 3 yıldır süregelen, kașıntılı ve papüller lezyonlar ile kliniğimize başvurdu. Klinik ve histopatolojik inceleme ile hastamız vulvar siringoma tanısı aldı. Semptomatik olan olgunun, tedavisinde lazer vaporizasyon yöntemi tercih edilmiş olup, vulvar lezyonların preoperatif ve postoperatif iyileşme süreçleri tartışılarak resimleri ile sunulmuştur.

Anahtar kelimeler: lazer vaporizasyon, vulvar siringoma

Türk Jinekoloji ve Obstetrik Derneği Dergisi, (J Turk Soc Obstet Gynecol), 2012; Cilt: 9 Sayl: 2 Sayfa: 116- 9

Address for Correspondence: Hakan Çoksüer. Gülhane Askeri Tıp Akademisi, Kadın Hastalıkları ve Doğum Anabilim Dalı, 06018 Etlik, Ankara Phone: (0542) 2462401

e-mail: coksuer@gmail.com

Received: 05 November 2010, revised: 17 February 2011, accepted: 10 March 2011, online publication: 31 March 2011 


\section{INTRODUCTION}

Syringomas are intradermal eccrin sweat gland tumors that cause dermal bulges. While it is mostly seen in adolescence, its prevalence at women is two-fold more than men. Also, progressive lesions may be encountered at latter ages ${ }^{(1)}$. Clinically, syringomas are small (1$3 \mathrm{~mm}$ of diameter), multiple, rigid lesions and they have the same color with skin or may be more yellowish. They are commonly located around at lower eyelids and nose but may be present at axillary region, neck, chest, upper arm and abdomen. The lesions are mostly bilateral and symmetrical ${ }^{(2-4)}$.

Vulvar syringomas are encountered extremely rare; hence there are few case reports in the literature. In this article, a vulvar syringoma case which had a confirmed diagnosis histopathologically is presented and the literature is reviewed.

\section{CASE}

A 35-aged, female case with 1 gravida and 1 parity who was referred to our clinic at March 2010 presented with persisting intermittent itchy lesions those had been ongoing for 3 years placed bilaterally at vulvar labias. No feature was present in self-history and family history and no pathological finding was seen at systemic examination. Frequent, 2-5 $\mathrm{mm}$ in diameter, forming plaques in patches, elastic, rigid papular skin lesions at both two labia majus and lower segment of mons pubis were detected by vulvar physical examination of the patient. Lesions were pallid yellow-brown, with smooth surfaces and elevated from the skin (Figure 1a). No similar lesion was seen at other sites of the body. Vulvar skin biopsy that was made with local anesthesia in policlinic conditions to make differential diagnosis of the case that suggested syringoma clinically; was reported as benign skin additive tumor with normal appearing keratinized squamos epithelium at surface, floored by single-row flattened cubical cells or cells with vacuole and cytoplasm at dermis, formed by dilated eccrin ducts (Figure 2). Our case was diagnosed as syringoma, in respect to these clinical and histopathological findings. Routine laboratory assessments of the case were evaluated as normal. For treatment of the lesions, laser vaporization was firstly suggested to the patient and patient's consent was taken. The patient was discharged at the same day after vulvar laser vaporization procedure performed under general anesthesia without any complication. The postoperative recovery process of the patient who was called for dressing follow-ups every other day was fast and successful. No recurrence was seen at the first month of follow-up and patient had full satisfaction (Figure 1b).

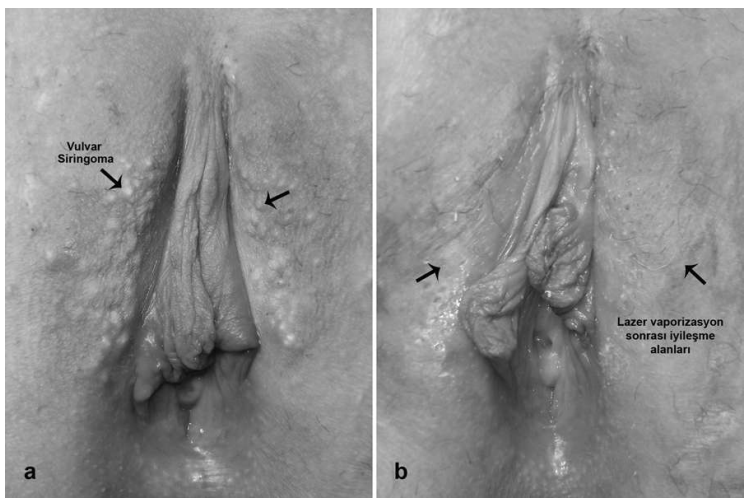

Figure 1a: Vulvar syringoma; lesions that are pallid yellow-brown, with smooth surfaces and elevated from the skin $\mathbf{1 b}$ : Vulvar recovery areas 3 weeks after laser vaporization.

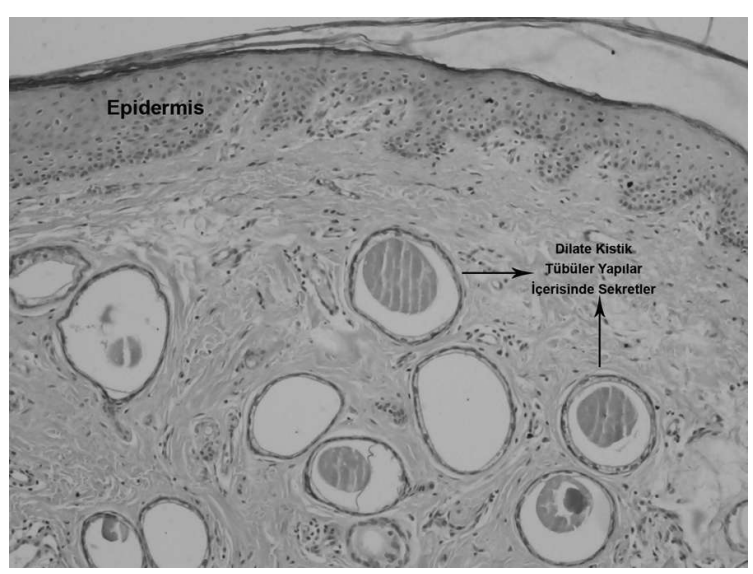

Figure 2: Vulvar biopsy histopathological image, secretas are seen inside of the dilated cystic tubular structures consistent with syringoma.

\section{DISCUSSION}

Syringomas were firstly described as tuberosum lymphangioma multiplex by Kaposi and Biesiadeki in $1872^{(5,6)}$. Since that date, the structure of intraepidermal eccrin sweat glands at this disorder has been examined by monoclonal antikeratin antibody tests, electron microscope and histochemistry studies ${ }^{(7)}$.

These tumors are commonly seen at adolescent women 
and they are mostly placed at face, under the eyes and malar region. Syringomas are typically asymptomatic, irreversible cases and malignity is reported rarely $(9)$. Although onset is commonly at puberty; as in our case, it may also be at further ages ${ }^{(8)}$.

Syringomas of genital region are rarely reported in the literature as sporadic cases. Similar to our case, intermittent pruritus complaining which increases during menstruation was reported in these publications ${ }^{(10)}$.

Syringomas may be present at approximately $20 \%$ of patients with Down syndrome. This rate is 30 -fold more than the rate in other diseases with mental retardation. Histopathological examination of syringomas seen in these cases revealed presence of calcinosis $(11,12)$. Calcinosis was not detected histopathologically and Down syndrome was not present at our case.

Although families with familial syringoma history were reported in the literature, for now a hereditary transmission could not be demonstrated for this disease $(7,13)$. Syringomas may be seen with Marfan syndrome and Ehler-Danlos syndrome(14). Family history was clear for our patient.

It is thought that hormonal factors also have role in the development of syringomas. Syringomas are thought to be sensitive to estrogen. The diameters of the lesions were reported to increase with pregnancy, premenstrual period and oral contraceptive use ${ }^{(14)}$. By demonstrating presence of estrogen and progesterone receptors at patients with extragenital syringoma, Wallace et al. supported the idea that syringomas would be under hormonal control ${ }^{(1)}$. In contrast, Huang et al. reported that they detected estrogen and progesterone receptors at none of the patients with vulvar syringoma(10).

In the light of histochemistry and electronmicroscopic findings, syringoma is an adenoma of eccrin ducts. Comma-shaped cystic ducts including amorphous substance surrounded with two lines of epithelium cells at dermis form typical histopathological image. Cysts with keratin may be present near to epidermis. These may sometimes be ruptured and cause foreign body reaction ${ }^{(15)}$.

Diagnosing vulvar syringomas is not challenging. But millia, verru plana, basal cell carcinoma, multiple nevoid basal cell carcinoma syndrome, eruptive vellus cyst, xanthomas, epidermal cysts, steocystoma multiplex, Fox-fordyce disease, condyloma accuminata, calcinosis cutis should be considered in differential diagnosis $(10,14)$. Also, liken planus and secondary syphilis should be considered at differential diagnosis of eruptive syringoma.

Follow-up with observation may be offered for asymptomatic cases with syringoma while symptomatic cases can be treated with electrocauterization, laser, topical atropine sulphate, topical tretionin and isotretionin. The best treatment method of syringomas is complete destruction of the tumor and it may be done with surgical excision, electrodessication, chemical peeling, topical atropine or tretinoin, cryosurgery and laser surgery $(14,16)$. Topical steroids and antihistamines are not effective. Topical atropine sulphate and tretinoin may be used successfully for treatment of pruritus ${ }^{(10)}$.

Although laser treatment is frequently preferred for treatment of skin tumors; it is reported in only a few cases with syringoma in the literature. In our case, laser vaporization was considered because it was more reliable as it was easy to perform, less painful, had less complication rate and better cosmetic outcomes.

In conclusion, syringomas should be kept in mind at differential diagnosis of cases present with complaining of vulvar pruritus at fertile period. Laser vaporization should be preferred at treatment of syringomas as it is safe and easy to perform. But prospective studies with more cases are needed to evaluate long-term recurrence and cosmetic outcomes.

\section{REFERENCES}

1. Wallace, M.L. and Smoller. B.R. Progesterone receptor positivity supports hormonal control of syringomas. J. Cutan. Pathol. 1995; 22: 442- 5

2. Ghirardini, G. Syringoma of the vulva in post-menopausal age. Diagn. Gynecol. Obstet. 1982; 4: 325- 8 .

3. Thomas, J., Majmudar, B., and Gorelkin, L. Syringoma localized to the vulva. Arch. Dermatol. 1979; 115: 95- 6 .

4. Belardi, M.G. Maglione, M.A. Vighi, S. and di Paola G.R. Syringoma of the vulva: a case report. J. Reprod. Med. 1994; 39: $957-9$.

5. Kaposi, M. Hebra diseases of the skin. Lymphangioma Tuberosum Multiplex. London, The New Sydendham Society. 1874; 3: 386.

6. Biesiadeki, A. Anatomischen Tuberosum multiplex: untersuchungen aus der Pathologisch Lymphangioma Institute in Krakau. Vienna: Wilhelm Braumuller; 1972, p 2.

7. Hashimoto, K., Gross, B.G., and Lever, W.F. Syringoma: histochemical and electron microscopy studies. J. Invest. 
Dermatol. 1966; 46: 150- 166.

8. Ghatt, H.J., Proia, A.D., and Tsoy, E.A. Malignant syringoma of the eyelid. Opthalmology 1984; 91: 987- 9.

9. Karaoğlu S., Eken A., Kontaş O. Siringoma (olgu sunumu). T Klin. Dermatoloji. 1994; 4(1): 32-4.

10. Huang YH, Chuang YH, Kuo TT, Yang LC, Hong HS. Vulvar syringoma: a clinicopathologic and immunohistologic study of 18 patients and results of treatment. J Am Acad Dermatol. 2003 May; 48(5): 735- 9.

11. Schepis C,Torre V, Siragusa M, Albiero F,Cicciarello R, Gagliardi ME, CavallariV. Eruptive Syringomas with calcium deposits in ayoung woman with Down's sendrome. Dermatology 2001; 203 (4): 345- 7.

12. Maroon M, Tylen W, Marks VJ. Calcinosis cutis associated with Syringomas; a transepidermal elimination disorder in a patient with Down Syndrome. J Am.Acud Dermatol. 1990 Aug; 23(2Pt2): 372- 5 .

13. Yesudion, P. and Thombiah, A. Familial syringoma. Dermatologica 1975; 150: $32-5$.

14. Burgdorf WHC:syringoma (syringocystadenoma).in: clinical Dermatology. Eds. Demis DJ,Thiers BH, Burgdorf WHC, Raimer SS, et al.19th ED. JB. Lippincott company publ, Philadelphia, 1992. Unit 22- 4: 1- 5.

15. Odom RB, James WD, Berger TG (eds). Andrews' Diseases of the Skin. Clinical Dermatology. 9th ed. Philadelphia: WB Saunders Company 2000: 69- 146.

16. Arnold HL,Odom RB,James WD:Diseases of the skin. 8th Ed.WB saunders company, Philadelphia, 1990; 791- 3. 